\title{
GEOPOLITYKA JAKO ŚWIATOPOGLĄD WŁADZY W ROSJI ${ }^{1}$
}

\author{
Konrad Świder \\ ISP PAN \\ e-mail: konrswider@gmail.com
}

\begin{abstract}
Streszczenie: Celem artykułu jest analiza tendencji i motywacji rządzących elit politycznych Rosji w zakresie myślenia o współczesnych stosunkach międzynarodowych. Myślenie to warunkowane jest przede wszystkim przez czynniki geopolityczne. Klasa polityczna Rosji nie jest jedyną, która w postrzeganiu systemu międzynarodowego odwołuje się do geopolitycznych interpretacjach. Podobny sposób myślenia właściwy jest Stanom Zjednoczonym czy Chinom. Uznanie przez Stany Zjednoczone Południowo-wschodniej Azji i przylegającej przestrzeni Oceanu Spokojnego za istotny dla tego państwa obszar globalnej polityki jest potwierdzeniem tej tendencji. Jednakże w Rosji geopolityka staje się obszarem wiedzy, który został włączony do nowego mesjanizmu tego państwa, stając się jednym z kamieni węgielnych myślenia o jego historycznym przeznaczeniu. Geopolityka w Rosji stała się swoistą ideologią w warunkach ideologicznej próżni jaka się wytworzyła po upadku komunizmu. Nastąpiła ideologizacja geopolityki, która dla elit politycznych stała się narzędziem interpretacji otaczającego systemu międzynarodowego i myślenia w kategoriach stref wpływów. Stała się cechą kultury strategicznej Federacji Rosyjskiej.
\end{abstract}

Słowa kluczowe: Rosja, geopolityka, elity władzy, kultura strategiczna, ład globalny

\section{WSTĘP}

Celem niniejszego artykułu jest przedstawienie cech i motywów myślenia o stosunkach międzynarodowych przejawianych przez rosyjskie elity władzy. Myślenie to jest zdeterminowane przez geopolitykę. Rosyjska klasa polityczna nie jest jedynym na świecie establishmentem opierającym się w swojej percepcji systemu światowego na interpretacjach geopolitycznych, gdyż podobny trend można obserwować w amerykańskich czy chińskich podejściach do tych zagadnień. Świadczy o tym chociażby uznanie w ostatnich latach przez Waszyngton Azji Południowo-Wschodniej i przylegającego do niej obszaru Pacyfiku za naj-

\footnotetext{
${ }^{1}$ Artykuł powstał w ramach grantu NCN nr UMO-2013/11/B/HS1/04144.
} 
ważniejszy kierunek globalnej polityki Stanów Zjednoczonych. Niemniej jednak w Rosji geopolityka stała się dziedziną wprzęganą w nowy mesjanizm rosyjski, będąc jednym $z$ fundamentów rosyjskiego przeznaczenia dziejowego i wypełniając nowymi treściami rosyjską historiozofię. Szczególny status geopolityki w Rosji wynika z faktu, że już w latach 90. XX w. stała się ona ideologią, która wypełniła próżnię ideologiczną po zbankrutowanej ideologii komunistycznej. Zatem nastąpił w tym kraju proces ideologizacji geopolityki, uzyskującej pozycję nowej idei powszechnej - całościowo wyjaśniającej Rosjanom, a w szczególności rosyjskiej elicie rządzącej, otaczający świat. Geopolityka oraz narzucana przez nią zdeterminowana geograficznie i przez myślenie kategoriami stref wpływów wizja systemu międzynarodowego stały się więc zarówno światopoglądem władzy w Rosji, jak i istotnym elementem rosyjskiej kultury strategicznej. W artykule zostaną przedstawione uwarunkowania czyniące $\mathrm{z}$ geopolityki trwały, archetypowy składnik myślenia o świecie i porządku globalnym w wydaniu elity rządzącej Rosją.

Geopolityka współcześnie odgrywa coraz większą rolę w stosunkach międzynarodowych - jako teoria i praktyka, pozwalając określić dążenia i cele polityczne względem siebie poszczególnych mocarstw, a nawet krajów mających mniejsze potencjały i możliwości. Światowy kryzys ekonomiczny z 2008 r. i związane z nim znaczące przewartościowania w polityce globalnej definitywnie przekreśliły kulejącą wówczas od co najmniej kilku lat liberalno-demokratyczną, tj. odzwierciedlającą się w modelu neoliberalnej globalizacji wizję „końca historii”, i spowodowały powrót do „determinizmu geopolitycznego”, stanowiąc jak gdyby zapowiedź powrotu do „koncertu mocarstw” - jako paradygmatu świata policentrycznego. Zjawisko to związane jest z erozją przywództwa i supremacji Stanów Zjednoczonych w świecie, jak również z renesansem myślenia o stosunkach międzynarodowych w kategoriach wielkiej geopolityki. Geopolityczna rywalizacja o strefy wpływów zastępuje dawną zimnowojenną konfrontację ideologiczną. ${ }^{2}$ Geopolityka szczególną rolę odgrywa w polityce amerykańskiej, europejskiej, chińskiej oraz oczywiście rosyjskiej. W niniejszym artykule zostanie opisany kontekst rosyjski tej globalnej tendencji (geopolityzacji stosunków międzynarodowych) - także w interakcji z innymi mocarstwowymi układami odniesienia.

\section{ASPEKTY TEORETYCZNE GEOPOLITYKI - ŚWIAT VERSUS ROSJA}

Od strony metodologicznej zagadnienie geopolityki jest bardzo złożone, co wiąże się z trudnościami rozstrzygnięcia kwestii czy geopolityka jest samodzielną dyscypliną naukową (odrębną nauką), paradygmatem badawczym czy też nauką

2 A. Walicki, Do wojny potrzeba dwóch stron. Dlaczego Putin kazał zając Krym i jaka w tym rolę odegraty Stany Zjednoczone, „Przegląd” 2015, nr 18 (800). 
pomocniczą lub szczególną metodą (instrumentem) analizy sytuacji międzynarodowej. Dotychczas wypracowano wiele definicji geopolityki. W ujęciach klasycznych geopolityka jest nauką o państwie jako organizmie geograficznym, tak jak wyraża się ono w przestrzeni, badającą państwa i ich politykę jako zjawiska przestrzenne (Rudolf Kjellen, twórca pojęcia ,geopolityka”); geopolityka jest świadomością geograficzną państwa, a jej przedmiot - badaniem politycznej formy życia w naturalnej przestrzeni życiowej oraz badaniem związków witalnych człowieka z przestrzenią (Karl Haushofer). Za najwybitniejszego spośród klasyków geopolityki uznaje się Johna Halforda Mackindera, który stworzył geopolityczną interpretację mapy globalnej, wskazując na niej najbardziej strategiczne regiony i wyjaśniając logikę rywalizacji o nie. ${ }^{3}$ Cechą charakterystyczną geopolityki klasycznej jest silny determinizm geograficzny, podkreślający znaczenie stałych czynników fizycznych i środowiskowych (np. terytorium, klimat, ukształtowanie terenu, zasoby naturalne). W związku z tym najogólniej można przyjąć, że geopolityka bada zmienne układy sił na niezmiennej przestrzeni. ${ }^{4}$

Dla niektórych badaczy geografia nie jest nauką, ale efektywną metodą analizy sytuacji międzynarodowej (Carlo Jean, Saul Cohen, czy poglądy przedstawicieli francuskiej szkoły geopolitycznej). Istota geopolityki sprowadza się w tym ujęciu do wnioskowania z zależności powstających między polityką międzynarodową a czynnikami geograficznymi. ${ }^{5}$ Saul Cohen wyróżnił łącznie sześć ujęć i metod geopolityki: ujęcie historyczne - badające ewolucję podmiotu geopolitycznego w stosunku do jego środowiska fizycznego i kulturowego, i zakładające, że jego obecna sytuacja i przyszły rozwój nie mogą zostać zrozumiane inaczej, jak tylko na podstawie jego przeszłości; ujęcie morfologiczne (geograficzne) - stosujące metodologię typową dla nauk geograficznych, dokonujące inwentaryzacji czynników stałych (fizycznych) i zmiennych (ludzkich) wpływających na szacunki geopolityczne; ujęcie funkcjonalne - analizujące funkcjonowanie obszaru pojmowanego jako jednostka polityczna, gospodarcza i strategiczna; ujęcie analizy potęgi - koncentrujące się na znaczeniu politycznym, strategicznym i gospodarczym obszaru rozumianego jako teren interakcji działających na nim wielu podmiotów politycznych; ujęcie behawiorystyczne - skoncentrowane bardziej na ocenie zamiarów niż na szacowaniach możliwości materialnych, badające systemy wartości, „,poczucie przestrzeni” i projekcje geopolityczne zbiorowej wyobraźni danego narodu; ujęcie systemowe - będące syntezą powyższych podejść. ${ }^{6}$ Włoski geopolityk Carlo Jean zdefiniował geopolitykę jako refleksję,

3 H. J. Mackinder, Geographical Pivot of History, „Geographical Journal” 1904, nr 4.

Halford J. Mackinder jest uznawany za twórcę tzw. potęgi kontynentalnej, a zaliczany również do twórców i klasyków geopolityki amerykański strateg Alfred Thayer Mahan - za twórcę tzw. potęgi morskiej. Jednak żaden z nich nie posługiwał się terminem ,geopolityka”, który został później upowszechniony przez Karla Haushofera.

4 L. Moczulski, Geopolityka. Potęga w czasie i przestrzeni, Warszawa 2000, s. 75.

5 Zob. S. Cohen, Geography and Politics in World Divided, New York 1963.

6 Ibidem, s. 7-15. 
metodę rozumowania, konceptualizację przestrzeni, nie tylko fizycznej, ale też ludzkiej i wielowymiarowej, która poprzedza i którą finalizuje wyodrębnienie interesów narodowych i wielkie wybory polityczne w świecie ulegającym szybkiej transformacji oraz równocześnie procesom globalizacji i fragmentaryzacji, w świecie, który potrzebuje bardziej reguł i ładu, jest coraz bardziej niepewny i konfliktowy, w którym ewolucja zjawisk jest coraz szybsza, podczas gdy nie nadąża za nią szybkość odpowiedzi.?

Warto zwrócić uwagę, że po drugiej wojnie światowej na obszarze anglosaskim oraz w ZSRR obłożono geopolitykę anatemą, gdyż uznano ją za światopogląd nazistowski i za główny stymulator hitlerowskiego ekspansjonizmu. Po zakończeniu drugiej wojny światowej, w nowych warunkach „zimnej wojny”, toczącej się między dawnymi sojusznikami z koalicji antyhitlerowskiej - Stanami Zjednoczonymi a Związkiem Radzieckim, jej uczestnicy przeformułowali geopolitykę w służbie swoich interesów globalnych. W Stanach Zjednoczonych zaczęto stosować termin ,geostrategia” (co współcześnie jest określane mianem geopolityki wojskowej), a w ZSRR realizowano ją pod postacią ekspansji ideologicznej czy teoretycznego instrumentarium ,internacjonalizmu komunistycznego”. Za oceanem ,dobre imię" geopolityce zaczęli w latach 70. XX w. przywracać Henry Kissinger i Zbigniew Brzeziński, choć ich geopolityka implikowała silne wpływy geostrategiczne.

Można założyć, że od lat 90. XX w. krystalizują się dwa główne nurty badań geopolitycznych, które mogą być określane jako dwie szkoły - neoklasyczna i poststrukturalna (postmodernistyczna, krytyczna). Szkoła neoklasyczna nawiązuje do okresu początku geopolityki - wpływu na nią koncepcji darwinizmu i organicyzmu społecznego oraz związanych z nimi determinizmów, podkreślając czynnik Realpolitik. Szkoła poststrukturalna, tzw. geopolityka krytyczna, odrzuca klasyczne podkreślanie analizy potęgi, pojęcia mocarstwa, suwerenności, konfliktów itd. (ponieważ w tym ujęciu przedmiot badań ma władzę nad podmiotem - indywidualnym lub zbiorowym) na rzecz badania procesów globalizacyjnych i glokalizacyjnych, aspektów kulturowo-psychologicznych, a także wyobrażeń przestrzennych przywódców państw i społeczeństw (tzw. kodów geopolitycznych). ${ }^{8}$ Geopolityka obejmuje szerokie spectrum paradygmatów (stylów myślenia), które mogą postrzegać świat i podmioty geopolityczne (ośrodki siły) jako: formy życia (paradygmat organiczny); świat jako system (paradygmat strukturalny); system międzynarodowy jako rywalizacja dwóch sił - tellurokracja versus talassokracja (paradygmat binarny [popularny w Rosji]). Geopolityczne style myślowe mogą także wprowadzać dekonstrukcję dyskursu geopolitycznego (paradygmat poststrukturalny) lub interpretować rzeczywistość geopolityczną

${ }^{7}$ C. Jean, Geopolityka, przeł. T. Orłowski i J. Pawłowska, Wrocław - Warszawa - Kraków 2003, s. 59.

8 Zob. J. Potulski, Wprowadzenie do geopolityki, Gdańsk 2010. 
w kategoriach Realpolitik (paradygmat realistyczny). ${ }^{9}$ Można więc przyjąć, że obecnie istnieją następujące kierunki (nurty) badań geopolitycznych: geopolityka klasyczna Halforda J. Mackindera; analiza układu sił w środowisku międzynarodowym, w tym geostrategia; geoekonomia; geopolityka krytyczna. ${ }^{10}$ Natomiast zasadniczymi problemami badawczymi geopolityki są: konflikty terytorialne/ przestrzenne; konflikty o zasoby; globalizacja; nowy porządek międzynarodowy; kody geopolityczne (autopercepcja geopolityczna), sposoby określania przez podmioty działające w środowisku międzynarodowym swoich opcji geopolitycznych; wyobrażenia geopolityczne. ${ }^{11}$

Bardzo ważnym elementem w „narracji geopolitycznej” jest wprowadzone przez najnowszy z kierunków geopolityki - nurt postmodernistyczny - pojęcie „dyskursu geopolitycznego”. Zagadnienie to podjęli m.in. irlandzki badacz Gearóid Ó Tuathail (ang. Gerard Toal) i znany brytyjsko-amerykański geograf polityczny John Agnew. Konceptualizowali oni dyskurs geopolityczny jako zespół zasobów społeczno-kulturowych użytych do konstruowania rozumienia świata i swojej w nim roli, a także jako zespół możliwości i całokształt reguł, z których pomocą odbiorcy lub nadawcy komunikatu (czytelnicy, słuchacze, mówcy) są w stanie przyjąć to i stworzyć całościową mapę świata. ${ }^{12}$ Ponadto pierwszy z tych autorów w okresie późniejszym odróżnił „dyskurs geopolityczny” od „dyskursu geostrategicznego". Dyskurs geopolityczny stanowi w jego przekonaniu umiejętne i zamierzone budowanie partykularnych sposobów myślenia o przestrzeni i stosunkach międzynarodowych przez instytucje oraz praktyków zajmujących się polityką zagraniczną; z kolei dyskurs geostrategiczny jest partykularną praktyką dyskursywną sposobów mówienia i opisywania zagadnień „bezpieczeństwa narodowego” oraz „strategicznych interesów” państwa. ${ }^{13}$

Teoretyzowanie geopolityczne mocno rozwinęło się w Rosji, w której istnieje szerokie spectrum rozważań nad geopolityką. Dostrzegalna jest tam silna tendencja do budowania wyjaśnień i interpretacji holistycznych (całościowych) w geopolityce, starających się integrować aspekty metafizyczne (mistyka przestrzeni, kult ziemi, apoteoza bezkresów jako naturalnego środowiska ducha narodu) z pragmatycznymi (możliwie szybkie osiąganie konkretnych i wymiernych korzyści w relacjach międzynarodowych) w osobliwy rosyjski paradygmat geopolityczny. Modnym i popularnym paradygmatem geopolitycznym w Rosji jest ujęcie geocywilizacyjne, pozycjonujące ten kraj zarówno jako ośrodek ge-

${ }^{9}$ Zob. L. Sykulski, Geopolityka, czyli pochwała realizmu. Szkice teoriopoznawcze, Warszawa 2011, s. 71-121.

${ }^{10}$ Zob. G. Smith, Geopolitics, [w:] The Dictionary of Human Geography, red. R. J. Johnston, D. Gregory, G. Pratt, M. Watts, Oxford 2000.

${ }^{11}$ Ibidem.

${ }^{12}$ G. Ó Tuathail, J. Agnew, Geopolitics and Discourse: Practical Reasoning American Foreign Policy, „Political Geography” 1992, nr 11, s. 192.

${ }^{13}$ G. Ó Tuathail, Geopolitics. Global Problems and Regional Concerns, [w:] Geopolitics. Global Problems and Regional Concerns, red. L. Tchantouridze, Winnipeg 2003, s. 98. 
opolityczny, jak i cywilizacyjny (Rosja jako centrum cywilizacji prawosławnej). Prekursorami tego paradygmatu byli Nikołaj Danilewskij (uznawany za twórcę nauki o cywilizacjach), Oswald Spengler, Arnold J. Toynbee, Feliks Koneczny, Philip Bagby czy Samuel Huntington. Ujęcie to okazało się niezwykle funkcjonalne i użyteczne $\mathrm{w}$ analizie rzeczywistości międzynarodowej świata postzimnowojennego, tworząc zbiór pojęć umożliwiających w przystępny sposób opisanie i zrozumienie dynamiki dokonujących się przemian politycznych w przestrzeni międzynarodowej, a także wskazując na potencjalne zagrożenia oraz źródła konfliktów. Paradygmat ten został upowszechniony we współczesnej nauce głównie przez amerykańskiego politologa Samuela Huntingtona - twórcę teorii „zderzenia cywilizacji”, która mimo pewnych własnych ograniczeń (uproszczeń w prezentacji problemów) stała się efektywnym i powszechnym narzędziem badawczym $\mathrm{w}$ analizie stosunków międzynarodowych. ${ }^{14}$ Ujęcie geocywilizacyjne niezależnie od swoich wad i niedociągnięć stanowi jeden z najpowszechniej wykorzystywanych przez geopolitykę (geopolityków) instrumentów metodologicznych $\mathrm{w}$ analizie środowiska międzynarodowego. Ten paradygmat dominuje w geopolityce rosyjskich eurazjatystów, reprezentowanych w tej materii najsilniej przez Aleksandra Dugina, który absolutyzuje geopolitykę, przekształcając ją w swoisty metasystem światopoglądowy i metaideologię, jak też podporządkowując jej wszystkie sfery życia politycznego i społecznego. Dugin wplata w geopolitykę treści metafizyczne, co nadaje jej formę jakby geozofii (świętej geografii). Rosyjski geopolityk definiuje swój przedmiot jako rządy nauki, jako naukę władzy i dla władzy, jako naukę o rządzeniu państwem. ${ }^{15}$

W Rosji istnieje również geopolityka akademicka oraz krytyczna. Zdaniem jednego z przedstawicieli tej pierwszej - Władimira Kołosowa geopolityka bada zależności polityki zewnętrznej i wewnętrznej państw oraz stosunków międzynarodowych od systemu wzajemnych powiązań politycznych, wojskowo-strategicznych, gospodarczych, ekologicznych, uwarunkowanych zarówno położeniem geograficznym kraju i jego regionów, jak też innymi czynnikami fizyczno- i ekonomiczno-geograficznymi; geopolitykę można traktować jako naukę o wpływie przestrzeni geograficznej na cele oraz interesy polityczne państwa. ${ }^{16} \mathrm{Z}$ kolei krytycznej refleksji nad geopolityką podjął się Dmitrij Zamiatin, który rozwinął kwestię tzw. kodów geopolitycznych. Przeanalizował on, w jaki sposób współcześni Rosjanie postrzegają samych siebie i świat zewnętrzny oraz jaka jest mapa świata w wyobrażeniach rosyjskich elit władzy i społeczeństwa. Wychodząc z założenia, iż tożsamość każdego kraju implikuje obrazy, wyobrażenia i postrzeganie otoczenia zewnętrznego, innych krajów i społeczeństw, na podstawie których kształtuje się

${ }^{14}$ Zob. S. P. Huntington, Zderzenie cywilizacji i nowy kształt ładu światowego, przeł. H. Jankowska, Warszawa 2001.

${ }^{15}$ А. Дугин, Основы геополитики. Геополитическое будущее России, Москва 2000, s. $13-14$.

${ }^{16}$ В. Колосов, Российская геополитика: Традиционные концепции и современные вызо$b b l$, „Общественные науки и современность” 1996, nr 3, s. 86. 
przeciwieństwo „my” i „oni”, autor ten uczynił kluczem swoich rozważań pojęcie „obrazów geopolitycznych”. Dmitrij Zamiatin rozumiał ten termin jako ukierunkowane i wyraźnie ustrukturyzowane wyobrażenia o przestrzeni geograficznej, zawierające najbardziej wyraziste i zachowane (utrwalone) w pamięci zbiorowej symbole, znaki, obrazy oraz charakterystyczne cechy określonych terytoriów, krajów czy też regionów, znakujące je z politycznego punktu widzenia. ${ }^{17}$ "Obrazy geopolityczne" stanowią osobliwy „metaobraz”, będący podstawą działania politycznego. Rosyjski autor uznał, iż główną rolę odgrywają tzw. kluczowe obrazy geopolityczne, które najsilniej strukturyzują wyobraźnię przestrzenno-polityczną. Obrazy te, będąc podstawową dla danego społeczeństwa formą opisania i uporządkowania przestrzeni, są przenoszone na rzeczywistą mapę polityczną świata i stają się podstawą pojawienia się specyficznych koncepcji geopolitycznych.

Na zakończenie teoretycznych rozważań o geopolityce warto zwrócić jeszcze uwagę na kwestię różnicy między geopolityką a geografią polityczną oraz wprowadzić istotne rozróżnienie między geopolityką koncepcyjną a operacyjną. W przeciwieństwie do geografii politycznej badającej pewne właściwości polityczno-geograficzne środowiska międzynarodowego w krótkim okresie, geopolityka bada to środowisko pod kątem długich cykli historycznych, starając się wychwycić pewne mechanizmy czy prawidłowości warunkujące potęgę tudzież powstanie, rozwój i upadek ośrodków politycznych ulokowanych w przestrzeni geograficznej. Z kolei na poziomie rozważań nad geopolityką koncepcyjną (teoretyczną) oraz geopolityką operacyjną (praktyczną, stosowaną) nasuwa się konkluzja, że w praktyce geopolityka staje się określoną (dokonywaną przez pryzmat pewnych kryteriów) subiektywną (dokonywaną przez dane państwo) interpretacją stosunków międzynarodowych; dlatego też w praktyce nie istnieje jednolita uniwersalna geopolityka (choć taki charakter mogą mieć mechanizmy geopolityczne), istnieją geopolityki poszczególnych państw.

\section{GEOPOLITYCZNE UWARUNKOWANIA ROLI I MIEJSCA ROSJI W SYSTEMIE MIĘDZYNARODOWYM}

Jak wspomniano wyżej, geopolityka w Rosji już w latach 90. XX w. stała się ideologią, która wypełniła próżnię ideologiczną po zbankrutowanej ideologii marksistowskiej. W oparciu o geopolitykę Federacja Rosyjska definiuje swoje

17 Д. Замятин, Власть пространства и пространство власти: Географические образы в политике и международных отношениях, Москва 2004; idem, Метагеография: Пространство образов и образы пространства, Москва 2004. W Polsce z problematyką tą korespondował Włodzimierz Marciniak; W. Marciniak, Mapa i pamięć o imperium. Kartograficzne symbole nostalgii postsowieckiej, [w:] Inne wymiary polityki, red. idem, Warszawa 2013, s. 139-164; Przestrzeń czy pustka? Pojęcie „prostranstwo” w rosyjskich debatach politycznych lat dziewięćdziesiatych XX wieku, [w:] Ofiary imperium. Imperia jako ofiary. 44 spojrzenia, red. A. Nowak, Warszawa 2010, s. 583-602. 
interesy narodowe oraz strategie polityki zagranicznej. Jednak trend determinizmu geopolitycznego - jakkolwiek nie skonceptualizowany w formie doktryny czy też dyscypliny akademickiej - był obserwowany w dziejach Rosji od momentu wkroczenia tego państwa na drogę ekspansji imperialnej, a więc od połowy XVI w. (zwycięstwo Rosji [ułusu moskiewskiego] w walce o spadek po imperium mongolsko-tatarskim - Złotej Ordzie). Rosyjska ekspansja imperialna stała się wyrazem nie tyle agresywnych dążeń politycznych Moskwy, co próbą przezwyciężenia skrajnie trudnych warunków geograficzno-klimatycznych oraz peryferyjnego położenia geograficznego, politycznego i gospodarczego, a także poszukiwania tzw. granic naturalnych. Zatem imperializm rosyjski w ciągu wieków w znacznej mierze miał charakter defensywny, będąc w Rosji nazywany imperializmem obronnym - również z uwagi na konieczność równoważenia wpływów i ekspansji politycznej innych potęg imperialnych w pobliżu granic Imperium Rosyjskiego.

Osobliwą cechą rosyjskiego myślenia politycznego jest terytoriocentryzm, wynikający z silnego organicystycznego przywiązania podmiotów sprawujących władzę w Rosji (car, cerkiew, szlachta) do ziemi, jej sakralizacji, i uczynienia z terytorium głównego elementu (wyznacznika) potęgi państwa, a następnie związanej z powyższymi kategoriami mitologii i symboliki narodowej. ${ }^{18}$ Kult przestrzeni geograficznej i bezkresów stał się przyczyną szybkiej adaptacji jeszcze w carskim Imperium Rosyjskim wypracowywanych na Zachodzie koncepcji geopolitycznych. W okresie Związku Radzieckiego oficjalnie odrzucono geopolitykę, ponieważ uznano, że zagraża ona (z racji swojej intelektualnej atrakcyjności) głównemu założeniu komunizmu - „walce klasowej”. Jednak w ZSRR geopolityka była realizowana na poziomie tzw. internacjonalizmu komunistycznego w ramach ideologicznej konfrontacji z kapitalizmem.

Zarówno geopolityka, jak i terytoriocentryzm stanowią istotny czy nawet dominujący składnik rosyjskiej kultury strategicznej. ${ }^{19}$ Można więc przyjąć, że na przestrzeni historii oraz obecnie geopolityka determinowała i wciąż determinuje rosyjską rację stanu, a także jest głównym polem odniesienia w walce o władzę

${ }^{18}$ Zob. S. Bieleń, Tożsamość międzynarodowa Federacji Rosyjskiej, Warszawa 2006, s. 125 131; idem, Geopolityczne uwarunkowania nowej tożsamości Rosji, [w:] Nowa tożsamość Niemiec i Rosji w stosunkach międzynarodowych, red. S. Bieleń, W. M. Góralski, Warszawa 1999, s. 78-83.

${ }^{19} \mathrm{~W}$ Rosji badania nad kulturą strategiczną jako autonomicznym problemem badawczym dopiero zaczynają być prowadzone. Dotychczas stanowiły one nienazwany w ten sposób element studiów nad bezpieczeństwem czy też strategią państwa, implikujących obszerne rozważania natury historycznej tudzież historiozoficznej. Wśród wielu opracowań na ten temat zob. В. Золотарев, Военная безопасность Государства Российского, Москва 2001; В. Якунин, Формирование геостратегий России, Москва 2005; А. Буркин, А. Возжеников, Н. Синеок, Национальная безопасность России в контексте современных политических проиесов, Москва 2005.

Niemniej jednak pojęcie to stopniowo toruje sobie drogę oraz miejsce w rosyjskiej politologii, czego symptomem jest powstawanie grup eksperckich i analitycznych czy think tanków zajmujących się tą problematyką. Jednym z nich jest np. Fundacja Kultury Strategicznej (Фонд Стратегической Культуры), publikująca swoje treści na stronie internetowej http://www.fondsk.ru, która sprawia wrażenie zwykłego portalu informacyjnego, zbieżnego z punktem widzenia Kremla. 
polityczną w tym kraju. W dziejach Rosji, w okresie imperialnym (od XVIII do XX w.) sankcję do tronu mógł uzyskać tylko ten władca lub polityk, który najlepiej wyrażał (lub kontynuował) geopolityczne interesy imperium (casus zabójstwa Piotra III czy Pawła I). Podobnie rzecz się ma we współczesnej Federacji Rosyjskiej, w której preferowane jest silne przywództwo zapobiegające rozpadowi państwa, a także podejmujące aktywne działania w kwestii integracji przestrzeni postradzieckiej. Odwiecznym problemem i największym zagadnieniem dziejowym Rosji jest bowiem zbieranie władzy i ziemi. Koncentracja szerokiej sfery regulacji w gestii jednego centrum władczego (instytucja samodzierżawia) podbudowana sankcją sakralną (prawosławie) i legitymacją ludową (ludowość) - wyrażona w doktrynie „oficjalnej ludowości” (narodnosti) z pierwszej połowy XIX w. - umożliwiała efektywny zarząd nad rozległym terytorium państwa poprzez podległy (i lojalny) temu centrum aparat biurokratyczny. Współcześnie zagadnienie imperium jest dla Rosjan bardziej kategorią estetyczno-symboliczną niż mającą swój desygnat (wyraz) w rosyjskiej praktyce politycznej. Niemniej jednak pojęcie imperium ma tam również pewne znaczenie funkcjonalne, gdyż identyfikowane jest jako konsolidujące wielkie przestrzenie państwa, będące podstawowym zasobem Rosji. Dlatego też geopolityka rosyjska cechuje się silnym determinizmem geograficznym i kartograficznym, a myślenie geopolityczne czy też geopolityczna percepcja otaczającej rzeczywistości jest w dużym stopniu rezultatem politycznych funkcji nauczania geografii w tym kraju.

Po rozpadzie Związku Radzieckiego nowopowstała Federacja Rosyjska, która ogłosiła się sukcesorem ZSRR i została za takiego uznana przez „,społeczność międzynarodową", próbowała się wkomponować w monocentryczny system międzynarodowy pod przywództwem Stanów Zjednoczonych. Przez pewien czas (do 1994 r.) godziła się z wyznaczonym jej przez Waszyngton statusem amerykańskiego junior partnera, wpisując się w koncepcję i praktykę amerykańskiego unilateralizmu. Jednak z powodu zdecydowanego odrzucenia przez administrację amerykańską rosyjskiej propozycji przekształcenia przestrzeni postradzieckiej w obszar dominacji Moskwy i odmowy Amerykanów dla uznania szczególnej roli Rosji w tym regionie, tzn. brak amerykańskiej akceptacji dla rosyjskiego wariantu doktryny Monroego, Rosja zmieniła swoją strategię globalną i zaczęła stopniowo promować model świata policentrycznego - wolnego od hegemonii Stanów Zjednoczonych. ${ }^{20}$ Głównymi celami rosyjskiej polityki zagranicznej stały się zdominowanie i integracja obszaru postradzieckiego pod egidą Moskwy, zabezpieczenie go przed polityczną i ekonomiczną ekspansją Zachodu, poszukiwanie partnerów zainteresowanych ograniczeniem amerykańskiej obecności w Eurazji (zbliżenie z Chinami i Iranem) ${ }^{21}$ Cele te w różnej kolejności (priorytetowości) wyrażano w kolejnych Koncepcjach Bezpieczeństwa Narodowe-

${ }^{20} \mathrm{Na}$ temat rosyjskiej doktryny Monroego zob. M. Smith, Pax Russica: Russias Monroe Doctrine, London 1993.

${ }^{21}$ Zob. A. Bryc, Cele polityki zagranicznej Federacji Rosyjskiej, Toruń 2004. 
go Federacji Rosyjskiej, w których z czasem za główne zagrożenie dla Rosji uznano ekspansję Paktu Północnoatlantyckiego na Wschód. ${ }^{22}$ Jakkolwiek Kreml wyraził zgodę na objęcie integracją euroatlantycką Europy Środkowej, a później Pribałtiki (państw bałtyckich), wyłączając je wcześniej ze swojej koncepcji przestrzeni postradzieckiej. Silny sprzeciw i znaczne poruszenie w Rosji, zwłaszcza w środowiskach formułujących koncepcje geopolityczne, wywołała książka wpływowego amerykańskiego politologa i geopolityka polskiego pochodzenia Zbigniewa Brzezińskiego (w przeszłości doradcy prezydenta Jimmy’ego Cartera), a konkretnie wyartykułowane w niej hegemonistyczne cele polityki globalnej Stanów Zjednoczonych - szczególnie w odniesieniu do obszaru szeroko rozumianej Eurazji. ${ }^{23}$ Tezy postawione przez Brzezińskiego, sprowadzające się do uzasadnień broniących amerykańskiej supremacji w świecie, korespondują z tzw. doktryną Wolfowitza przewidującą utrzymanie i umacnianie przez Stany Zjednoczone uzyskanego po „zimnej wojnie” statusu jedynego supermocarstwa światowego. ${ }^{24}$ Koncepcja ta, sformułowana w 1992 r. i nazwana Defense Planning Guidance, której współautorem był amerykański podsekretarz obrony Paul Wolfowitz (obok Lewisa Libby'ego), mimo iż była szeroko krytykowana jako imperialistyczna, i mimo że formalnie odcinała się od niej administracja amerykańska, stała się jednak w przyszłości fundamentem tzw. doktryny Busha. ${ }^{25}$ Doktryna Wolfowitza

${ }^{22}$ Pozycja Rosji w systemie międzynarodowym w poszczególnych okresach po rozpadzie Związku Radzieckiego znajdowała wyraz w Koncepcjach bezpieczeństwa narodowego Federacji Rosyjskiej. Dokumentem wyjściowym, podlegającym kolejnym redakcjom, modyfikacjom czy też nowelizacjom (w zależności od sytuacji międzynarodowej) była Koncepcja bezpieczeństwa narodowego Federacji Rosyjskiej z 17 grudnia 1997 r. W następnej wersji zatwierdzono ją 10 stycznia 2000 r. Najnowszy wariant włącznie z dokumentem Strategia bezpieczeństwa narodowego Federacji Rosyjskiej do 2020 roku został przyjęty 12 maja 2009 r. Ten ostatni dokument zmodyfikowano 1 lipca 2014 r. Zob. Концепция национальной безопасности Российской Федераџии, „Дипломатический вестник” 1998, nr 1; Конщепџия наџиональной безопасности Российской Федерачии, „Дипломатический вестник” 2000, $\mathrm{nr}$ 2. Стратегия начиональной безопасности Российской Федераиии до 2020 года, http://base.garant.ru/195521/\#block_1000 [dostęp: 25 lipca 2015]. Przedstawione wyżej koncepcje bezpieczeństwa narodowego, jak również koncepcje polityki zagranicznej, strategii rozwoju oraz doktryny obronne stanowią najpełniejszy wyraz rosyjskiej kultury strategicznej.

${ }^{23}$ Z. Brzeziński, Wielka szachownica. Główne cele polityki amerykańskiej, przeł. T. Wyżyński, Warszawa 1998.

${ }^{24}$ U.S. Strategy Plan Calls for Insuring No Rivals Develop A One-Superpower World. Pentagon's Document Outlines Ways to Thwart Challenges to Primacy of America, by P. E. Tyler, „The New York Times", 8 marca 1992. W ostatnich miesiącach, w związku z zaangażowaniem się Rosji w konflikt w Syrii po stronie prezydenta Baszszara al-Asada, pojawiają się opinie, że Kreml zdołał przełamać doktrynę Wolfowitza; zob. Putin Has Just Put An End to the Wolfowitz Doctrine, http:// www.washingtonsblog.com/2015/10/putin-has-just-put-an-end-to-the-wolfowitz-doctrine.html [dostęp: 25 stycznia 2016].

${ }^{25}$ Doktryna Busha (linia w polityce zagranicznej Stanów Zjednoczonych przyjęta przez administrację Georga W. Busha) w sferze politycznej przewidywała wspieranie rozprzestrzeniania się na świecie klasycznego liberalizmu wraz z jego instytucjami i wartościami, z kolei w sferze wojskowej zakładała możliwość wykonania przez Waszyngton „wyprzedzającego uderzenia”, tzn. 
wskazywała na nietrwałość przemian demokratycznych w Rosji, dążenia Moskwy do dominacji na obszarze postradzieckim i zwracała uwagę na fakt, że Rosja jest jedynym państwem na świecie zachowującym wobec Stanów Zjednoczonych parytet zniszczenia nuklearnego.

Amerykańskie projekty i wizje porządku międzynarodowego wywoływały na Kremlu irytację, niemniej jednak Moskwa wyszła wobec Waszyngtonu z ofertą ocieplenia wzajemnych relacji po zamachu z 11 września 2001 r. na World Trade Center w Nowym Jorku. Na początku wspierała nawet amerykańską inwazję na Afganistan, uzyskując w zamian dyskredytację spacyfikowanego wcześniej czeczeńskiego ruchu niepodległościowego, który światowe media zaczęły prezentować jako część międzynarodowego terroryzmu, co akurat do pewnego stopnia znajdowało potwierdzenie $\mathrm{w}$ faktach. Jednak przychylność Moskwy dla polityki Stanów Zjednoczonych skończyła się w momencie agresji Waszyngtonu na Irak pod fałszywym pretekstem posiadania przez ten kraj broni masowego rażenia (na co w Rosji wskazywano od razu). Stosunki ze Stanami Zjednoczonymi wyraźnie pogorszyły się po wspieranej przez Waszyngton i jego środkowoeuropejskich sojuszników (m.in. Polskę) ,rewolucji pomarańczowej” na Ukrainie. Administracja kremlowska, którą od początku 2000 r. reprezentował następca Borysa Jelcyna - ograniczający demokratyczne reguły gry politycznej - prezydent Władimir Putin, zinterpretowała ją jako wymierzone w Rosję wtargnięcie Zachodu w przestrzeń postradziecką i zapowiedź kolejnej „kolorowej rewolucji” - tym razem już w Moskwie. W ten sposób doszło do wznowienia rywalizacji rosyjsko-amerykańskiej o wpływy w przestrzeni postradzieckiej, którą Rosja uznaje za swoją wyłączną strefę wpływów, co spotyka się ze sprzeciwem Stanów Zjednoczonych $\mathrm{i}$ ich sojuszników (w tym m.in. Polski). Moskwa postrzega politykę Waszyngtonu w kategoriach destabilizowania kolejnych regionów w celu osiągania przez Amerykanów geopolitycznych i geoekonomicznych korzyści (Bliski i Środkowy Wschód, północna Afryka).

Kolejne lata przyniosły dalsze pogorszenie się stosunków Rosji ze Stanami Zjednoczonymi, czego egzemplifikacją była krótka zwycięska wojna z Gruzją w sierpniu 2008 r., reakcja Moskwy na amerykańskie plany wobec Syrii i powstrzymanie amerykańskiej interwencji w tym kraju w 2013 r. oraz na wspieraną przez Zachód „eurorewolucję” na Ukrainie z przełomu 2013 i 2014 r. Rosja zaanektowała należący do Ukrainy, lecz zamieszkany w większości przez Rosjan (przeciwnych nowym władzom w Kijowie) Krym, łamiąc w ten sposób prawo międzynarodowe i naruszając integralność terytorialną państwa ukraińskiego. Kolejnym działaniem Rosji na Ukrainie było wydatne wsparcie separatystów w Donbasie, które umożliwiło im de facto wyjście spod władzy Ukrainy i odnie-

prewencyjnego ataku militarnego na każde państwo stanowiące lub mogące stanowić zagrożenie dla Stanów Zjednoczonych. Doktryna Busha spotykała się z silną krytyką ze strony społeczności międzynarodowej, zarzucającej jej ignorowanie autorytetu ONZ oraz prowokowanie nowych konfliktów w zapalnych regionach świata; zob. W. Szymborski, Doktryna Busha, Bydgoszcz 2005. 
sienie zwycięstwa. Rosyjskie działania na Krymie były motywowane również chęcią uniemożliwienia w przyszłości przejęcia rosyjskich baz wojennych przez Amerykanów oraz ochroną rosyjskiej głębi strategicznej na odcinku ukraińskim. W optyce Kremla Biały Dom kontynuuje bliskowschodnią politykę na Ukrainie, próbując rozciągnąć strefę „strategicznej niestabilności” na obszar postradzieckiej Eurazji poprzez tworzenie nowych punktów konflagracyjnych (zapalnych), co z kolei zmusza Kreml do działań kontrkonflagracyjnych (tworzenie kontrpunktów zapalnych). W tym kontekście Moskwa swoją politykę w stosunku do Ukrainy uznaje za defensywną względem amerykańskiego ekspansjonizmu i hegemonicznego projektu świata monocentrycznego. Natomiast z perspektywy Zachodu działania Rosji mają charakter imperialny i są ewidentnym powrotem do najgorszych tradycji rosyjskiego imperializmu, co wzbudza szczególne obawy oraz niepokój w Warszawie, Wilnie, Rydze i Tallinie. Rywalizacja o postradziecką Eurazję jest postrzegana zarówno w Rosji, jak i w Stanach Zjednoczonych jako konfrontacja geopolityczna, czego wyrazem są oficjalne enuncjacje polityków obu mocarstw. Jednak reprezentanci rosyjskiej klasy politycznej wydają się znacznie silniej niż politycy amerykańscy polegać na geopolitycznych uzasadnieniach swoich decyzji i opinii. Jednak przestrzeń postradziecka nie jest jedynym obszarem, na jakim dochodzi do starcia geopolitycznych wizji Rosji i Stanów Zjednoczonych. Między oboma mocarstwami występują tarcia związane z rywalizacją w Arktyce oraz z rosyjskim zaangażowaniem militarnym w Syrii po stronie zwalczanego przez Waszyngton prezydenta Baszszara al-Asada. Kreml w ten sposób stara się dać do zrozumienia Białemu Domowi, że tak samo jak Stany Zjednoczone ingerują na obszarze postradzieckim, tak samo Rosja może mieć strategiczne interesy w regionie postrzeganym jako amerykańska strefa wpływów.

\section{GEOPOLITYCZNE WYOBRAŻENIA ROSYJSKICH ELIT WŁADZY}

Eksplozję i powszechność geopolityki w Rosji po rozpadzie ZSRR można spróbować wyjaśnić jako jedną z metod racjonalizacji nostalgii czy traumy poimperialnej lub dysonansów tożsamościowych (kryzysu tożsamości) powstałych w wyniku dezintegracji imperium radzieckiego. Poprzez geopolitykę poszukiwano odpowiedzi na pytania dotyczące roli i miejsca Rosji w postzimnowojennym świecie. Władze Rosji szybko rozpoznały zjawisko substytucji ideologicznej, jaka zachodziła na poziomie zastępowania ujęć i wyjaśnień marksistowskich interpretacjami geopolitycznymi. Wymownie ten stan rzeczy streścił pierwszy minister spraw zagranicznych Federacji Rosyjskiej, Andriej Kozyriew, który w wywiadzie dla „Rossijskoj gaziety” z 12 stycznia 1992 r. oznajmił: „Rezygnując z mesjanizmu, torujemy drogę pragmatyzmowi... szybko zdaliśmy sobie sprawę, że ideologię... zastępuje geopolityka". ${ }^{26}$ Jednak w Rosji geopolityka nie zastępo-

${ }^{26}$ Cyt. za: Z. Brzeziński, op. cit., s. 122. 
wała ideologii jako takiej, ponieważ sama stawała się ideologią - co najwyżej zastępującą poprzednią ideologię. Nie była też antytezą wobec mesjanizmu, stała się zuniwersalizowaną metodą poszukiwania i eksploatacji nowych formuł mesjanistycznych - adekwatnych dla epoki postmodernizmu. Rosyjska klasa polityczna ulegała jednak pewnym wizjom konstruowanym przez geopolitykę (co w tym kraju miało w znacznym stopniu charakter życzeniowy), np. równorzędnego statusu Rosji wobec Stanów Zjednoczonych, by potem w bolesny dla siebie sposób - w wyniku amerykańskiej negacji rosyjskich projektów geopolitycznych i wizji porządku międzynarodowego - odnajdywać właściwą miarę rzeczy. Sam Andriej Kozyriew w wywiadzie dla gazety „Izwiestia” z 11 marca 1994 r. otwarcie wyraził pogląd, iż Stany Zjednoczone dążą do światowej hegemonii kosztem Rosji. ${ }^{27}$

Od pewnego już czasu rosyjskie kręgi liberalne - rządzące wówczas Rosją wskazywały światu uznanie supremacji Moskwy w przestrzeni postradzieckiej jako jeden z głównych warunków utrzymania i ugruntowania demokracji w Rosji, która jest zagrożona przez atrakcyjną dla wielu Rosjan retorykę „rewanżu imperialnego" uprawianą przez rozmaite radykalne grupy, środowiska i partie polityczne. Tak powstała nieformalna koncepcja „liberalnego imperium”, do której oficjalnie powrócono w 2003 r. i którą reaktywował Anatolij Czubajs. ${ }^{28}$ Projekt liberalnego imperium opierał się m.in. na założeniu, że Zachód poprze tę koncepcję. Czubajs zaproponował Zachodowi transakcję wiązaną: Zachód uzna strefę wpływów Rosji, za co otrzyma wolnorynkową i być może demokratyczną, a z pewnością stabilną Rosję wraz z jej najbliższym otoczeniem. ${ }^{29}$ Plany Moskwy zostały jednak pogrzebane przez „rewolucję pomarańczową” na Ukrainie z końca 2004 r. Projekt „liberalnego imperium” miał być więc strawnym dla Zachodu uzasadnieniem rosyjskich aspiracji do hegemonii w postradzieckiej Eurazji. Był też jednym z sygnałów, że Rosja nie zgodzi się na nierównoprawny status wobec Zachodu, w szczególności w odniesieniu do obszaru postradzieckiego. ${ }^{30}$

W kontekście geopolitycznym można obserwować w Rosji wybiórczy (tzn. pod założone tezy) obrót najpopularniejszymi i najmodniejszymi współczesnymi zachodnimi koncepcjami oraz dyskursami politologicznymi, cywilizacyjnymi czy historiozoficznymi. Z entuzjastycznym przyjęciem spotkały się wśród rosyjskich środowisk inteligenckich koncepcja konfliktu cywilizacji Samuela Huntingtona i konstruktywistyczna teoria nacjonalizmu Benedicta Andersona, ukazująca w rosyj-

${ }^{27}$ Zob. M. Czajkowski, Rosja w Europie. Polityka bezpieczeństwa europejskiego Federacji Rosyjskiej, Kraków 2003, s. 97.

${ }^{28}$ Jarosław Bratkiewicz projekt „liberalnego imperium” nazwał „ideą kozyriewowską”, przypisując jej autorstwo Andriejowi Kozyriewowi; J. Bratkiewicz, Zapętlenia modernizacji. Szkice o samopostrzeganiu i autoidentyfikacji w interakcjach tradycji i nowoczesności (przypadek Rosji i nie tylko), Warszawa 2007, s. 347-348.

${ }^{29}$ I. Krastev, Putinowskie ,spoteczeństwa obywatelskie”?, http://www.dziennik.pl/dziennik/europa/article47052/Putinowskie_spoleczenstwa_obywatelskie_.html [dostęp: 26 października 2005].

${ }^{30}$ Zob. A. Orlov, Russia Will Never Accept the Role of a Poor Relation, „International Affairs: A Russian Journal of World Politics, Diplomacy and International Relations” 2004, t. 50, nr 4. 
skim jej odbiorze narody jako wspólnoty wyobrażone, wymyślone lub wynalezione, które to tezy nierzadko są argumentem Rosjan w ich publicystycznych dyskusjach z okolicznymi geograficznie czy pokrewnymi plemiennie nacjami, kwestionujących historyczność określonych narodów, jakkolwiek najwyższe władze rosyjskie (administracja Kremla) nie dopuszczają się takich praktyk. ${ }^{31}$ Natomiast krytycznie przyjęto w Rosji koncepcję „końca historii” Francisa Fukuyamy, przewidującą zmierzch z końcem „zimnej wojny” epoki ideologii i tryumf demokracji liberalnej. Tezy amerykańskiego politologa, filozofa i ekonomisty stoją w opozycji do punktu widzenia większości rosyjskiej inteligencji (w tym klasy politycznej), gdyż poprzez apologię zachodniej ścieżki cywilizacyjnej dezawuują rosyjskie doświadczenie cywilizacyjne, spychając je do „lamusa historii”. ${ }^{32}$ Zatem projekcja fukuyamowska została w Rosji zdecydowanie odrzucona. Nawet w samych Stanach Zjednoczonych zdano sobie sprawę z iluzji „mitu neoliberalnego" i ogłoszono „powrót historii”. Jednak uczyniono z tej enuncjacji instrument krytyki geopolitycznych strategii Rosji czy Chin, ponieważ zdaniem części amerykańskich czynników oficjalnych państwa te realizują swoje interesy, stosując metody dziewiętnastowieczne. ${ }^{33}$

Takiej deprywacji Rosji zapobiega paradygmat huntingtonowski, stawiający Rosję w szeregu głównych centrów cywilizacyjnych globu (cywilizacja prawosławna) i wyznaczający jej ważne i odpowiedzialne funkcje jako jednemu ze światowych liderów. W przekonaniu Samuela Huntingtona po zakończeniu „zimnej wojny” świat wszedł w epokę eskalacji nastrojów fundamentalistycznych („,rewanż Boga") i wynikających stąd sprzeczności między siedmioma lub ośmioma głównymi cywilizacjami, wewnętrznie skonsolidowanymi wokół tradycyjnych religii. W tej sytuacji Rosja z jednej strony jako centrum cywilizacyjne ponosi odpowiedzialność za utrzymanie pokoju oraz stabilności w „strefie prawosławnej”, zabezpieczając przy tym - w ramach troski o równowagę międzycywilizacyjną - cywilizację prawosławną przed potencjalną agresją wychodzącą ze strony innych obszarów cywilizacyjnych, a z drugiej - powinna się pogodzić z odejściem części swojej dawnej strefy wpływów (Pribattiki, Azji Środkowej) do innych, właściwych im, cywilizacji.

Zdaniem rosyjskiego socjologa Leonida Jonina schemat huntingtonowski dał wiele satysfakcji badaczom rosyjskim, dostrzegającym w nim cechy własnego narodowego sposobu i stylu myślenia. ${ }^{34}$ Teoria Huntingtona została pozytywnie przyjęta w Rosji z kilku powodów - m.in. dlatego, że okazała się bliska narodowemu stylowi geopolitycznych i historiozoficznych spekulacji; że Rosja bardziej niż inne kraje odczuwa zagrożenie ze strony islamskiego fundamentalizmu i natarcie na Północ „wojującej” cywilizacji muzułmańskiej; że Huntington

${ }^{31}$ Zob. S. P. Huntington, op. cit.; B. Anderson, Wspólnoty wyobrażone: Rozważania o źródłach i rozprzestrzenianiu się nacjonalizmu, tłum. S. Amsterdamski, Kraków 1997.

${ }^{32}$ Zob. F. Fukuyama, Koniec historii, przekł. T. Bieroń, M. Wichrowski, Poznań 1996.

${ }^{33}$ Zob. R. Kagan, Powrót do historii i koniec marzeń, przeł. G. Sałuda, Poznań 2009.

34 Л. Ионин, Социология культуры: Путь в новое тысячилетие. (Учебное пособие для студентов вузов), Москва 2000, rozdz. 5: Геополитика и глобализм, http://www.gumer.info/ bibliotek_Buks/Sociolog/Ionin/_05_1.php [dostęp: 23 listopada 2015]. 
uznał ważną rolę Rosji w swoim scenariuszu geopolitycznym. ${ }^{35}$ Znaczna część rosyjskiej inteligencji - zwłaszcza z kręgów nacjonalistycznych - zainspirowana huntingtonowską projekcją, odważnie postawiła znak równości między prawosławiem a słowiańskością i uznała Rosję za centrum cywilizacji słowiańskiej. Koncepcja „zderzenia cywilizacji” w sposób naukowy (w duchu nauk społecznych) sankcjonowała aspiracje i pretensje Rosji do statusu regionalnego lidera, łagodziła syndrom zdegradowanego imperium - będąc „,balsamem na jej duszę”, i nie jest istotne, że stanowiła jakby kalkę doktryny Breżniewa. ${ }^{36} \mathrm{~W}$ tej optyce szczególnymi obszarami wpływów rosyjskich są Ukraina, Białoruś i Kazachstan. Wobec tego uprawniona wydaje się konkluzja, iż teorie Huntingtona czy Andersona stanowią treściwy i inspirujący ideowo podkład współczesnego rosyjskiego myślenia geopolitycznego, zawdzięczającego koherencji z głównymi trendami w politologii anglosaskiej legitymizację ze strony nauki zachodniej.

Umysłowi rosyjskiemu, często i nawykowo postrzegającemu świat w kategoriach wielkich przestrzeni, raczej trudno pogodzić się z obecną dominacją paradygmatu narodu-nacji (tj. politycznej wspólnoty obywatelskiej, ukształtowanej w procesie historycznym) i deprecjacją formuły imperialnej (Rosjanie preferują dyskurs narodu-etnosu - wspólnoty etniczno-językowej; oraz narodu-superetnosu - państwowej wieloetnicznej wspólnoty imperialnej). ${ }^{37}$ Jednak obecnie w Federacji Rosyjskiej kategoria narodu-nacji wydaje się mieć swój renesans, ponieważ jest ona w sferze wyobrażeń znacznie mniej amorficzna niż pojęcie wspólnoty imperialnej (cywilizacyjnej czy religijno-kulturowej) i lepiej się nadaje na budulec tożsamości. Toteż we współczesnej Rosji można obserwować inspirowaną przez władze tendencję do wtórnej nacjonalizacji (rusyfikacji) rosyjskiego dziedzictwa imperialnego, czego egzemplifikację stanowi choćby koncepcja russkogo mira, opierającego się na idei integracji oraz kultywowania wspólnoty narodowo-kulturowej i historyczno-politycznej ,ruskich (rosyjskich) ludzi”, głównie na obszarze postradzieckim. ${ }^{38}$

\section{${ }^{35}$ Ibidem.}

${ }^{36}$ Ibidem.

${ }^{37}$ Toteż nawet wśród liberalnych politologów w Rosji popularne są koncepcje takich badaczy jak Ernest Gellner, Eric Hobsbawm czy Elie Kedourie, zakładające jakby sztuczny (będący efektem modernizacji społeczno-gospodarczej, politycznego konstruowania czy sterowania świadomością zbiorową) charakter wspólnot narodowych; zob. E. Gellner, Narody i nacjonalizm, przekł. T. Hołówka, Warszawa 1991; E. Hobsbawm, Narody i nacjonalizm po 1780, tłum. J. Maciejczyk, M. Starnawski, Warszawa 2010; E. Kedourie, Nationalism, London 1993.

${ }^{38}$ Zob. A. Wierzbicki, Russkij mir jako projekt restauracyjny imperium, [w:] Rosja. Rozważania imperiologiczne, red. S. Bieleń, A. Skrzypek, Warszawa 2015.

Koncepcja russkogo mira (ruskiego świata) podejmowana jest i rozwijana w konserwatywnych prokremlowskich stowarzyszeniach inteligenckich, którym czasami (jak np. w początkowym okresie kryzysu politycznego na Ukrainie z przełomu 2013 i 2014 r.) pozwala się na występowanie w roli suflerów Kremla. Jednym z takich stowarzyszeń jest powstały we wrześniu 2012 r. Klub Izborski - zrzeszający antyzachodnich prokremlowskich intelektualistów, mających zdolność kreowania polityki Moskwy. Stowarzyszenie to ma formułę klubu eksperckiego (think tanku), 
Po rozpadzie ZSRR powszechny dyskurs geopolityczny towarzyszył procesowi pluralizacji ideologiczno-politycznej. Każda opcja światopoglądowa miała swój obraz geopolityki, a inklinacje geopolityczne były cechą rosyjskiej debaty publicznej już od czasów późnej pieriestrojki - od ogłoszenia polityki głasnosti (jawności), kiedy to zerwano z ,jedynie słuszną" marksistowską wizją świata. Nie licząc komunistów rytu radzieckiego, tkwiących w ideowo-politycznej dezintegracji, dominującymi - lecz światopoglądowo amorficznymi - orientacjami ideowymi w postpieriestrojkowej Rosji byli „demokraci” (utożsamiani z sziestidiesiatnikami) oraz „patrioci” (poczwienniki); z czasem opcje te zaczęły się jeszcze różnicować na liberałów, komunistów (narodowych), centrystów i radykałów. ${ }^{39}$ Zatem ideowe spectrum Federacji Rosyjskiej składało się ze spadkobierców gorbaczowowskiego „nowego myślenia politycznego”, atlantystów (zapadnikow), eurazjatystów (słowianofilów i izolacjonistów), państwowców-mocarstwowców (dierżawnikow, gosudarstwiennikow i silowikow) oraz pragmatyków. ${ }^{40} \mathrm{~W}$ tym labiryncie mozaiki światopoglądowej sporym wyzwaniem badawczym jest wyjaśnianie różnic politycznych pomiędzy licznymi szkołami myślenia, obozami politycznymi czy grupami interesów; brakuje przejrzystych kryteriów wyłaniania orientacji ideowo-programowych. Znaczną trudność - z powodu podobnego stosunku do tradycji imperialnej, mocarstwowości i nacjonalizmu - stanowi ponadto znajdowanie dowodów wpływu poszczególnych szkół myślenia na decydentów politycznych. Zatem w zasadzie każdy nurt ideowy w Rosji dążył do posiadania „,własnej” geopolityki od liberałów po komunistów, konserwatystów, tradycjonalistów czy nacjonalistów.

Prądem ideowym, który w Rosji wynosi geopolitykę ponad inne formy percepcji stosunków międzynarodowych, jest euroazjatyzm (neoeurazjatyzm). Stanowi on bardzo pojemny nurt, niepozwalający się całkowicie utożsamić z jakąkolwiek klasyczną ideologią, i występujący w wielu odmianach - demokratycznej lub liberalnej/umiarkowanej, słowianofilskiej, konserwatywnej czy też (neo)komunistycznej. ${ }^{41}$ Pierwszymi najbardziej znaczącymi i sztandarowymi publikacjami w postradzieckiej Rosji, szeroko traktującymi o geopolityce były opublikowane w 1997 r. manifest Giennadija Ziuganowa Gieografija pobiedy (Geografia zwycięstwa) i - zwłaszcza - Osnowy gieopolitiki (Podstawy geopolityki) Aleksandra Dugina ${ }^{42}$ Ostatni z tych autorów jest reprezentantem i liderem konserwatywnego

zajmuje się badaniem i analizą rosyjskiej polityki wewnętrznej i zagranicznej. Klub Izborski ma stanowić swojego rodzaju antytezę (antidotum) Klubu Wałdajskiego, tworzonego przez liberalnych intelektualistów rosyjskich jak też zagranicznych ekspertów od polityki wewnętrznej i zewnętrznej Rosji. Zob. oficjalna strona Klubu Izborskiego: http://www.dynacon.ru ; zob. K. Świder, Klub Izborski wobec Ukrainy, „Studia Polityczne” 2015, t. 38, nr 2, s. 121-137.

${ }^{39}$ Zob. С. Константинов, А. Ушаков, История после истории. Образы России на постсоветском пространстве, Москва 2001, s. 17-23.

${ }^{40}$ Zob. S. Bieleń, Tożsamość międzynarodowa Federacji Rosyjskiej, s. 61.

${ }^{41}$ Ibidem, s. 71-78; Л. Ионин, op. cit.

${ }^{42}$ Zob. Г. Зюганов, География победы: Основы российской геополитики, Москва 1997 (pozycja do pobrania na http://www.bookz.ru/authors/gennadii-zuganov.html [dostęp: 23 listopada 2015]). W przypadku książki Aleksandra Dugina korzystałem z jej rozszerzonego wydania 
odłamu eurazjatyzmu. Dugin, mający silne koneksje z wpływowymi przedstawicielami rosyjskiej elity władzy, uchodzi za najbardziej wpływowego i wyrazistego rosyjskiego geopolityka, który wiele publikuje, ale wartość merytoryczna jego publicystyki bywa kwestionowana zarówno w Rosji, jak i zagranicą. ${ }^{43}$ Powszechnie zwraca się uwagę na aspekt ideowy eurazjatyzmu (Rosja jako odrębna, szczególna cywilizacja), zapominając jednak o bardziej pragmatycznej podstawie (punkcie wyjścia) tej ideologii, a mianowicie - koncepcji równomiernej alokacji zasobów na ogromnych przestrzeniach Rosji, pozyskiwania ich z azjatyckiej części kraju jako warunku jego mocarstwowości. ${ }^{44} \mathrm{Na}$ uwagę zasługują też wyrażone chronologicznie nieco wcześniej wizje geopolityczne Władimira Żyrinowskiego, stanowiące jakby kalkę niemieckich klasycznych przedwojennych koncepcji geopolitycznych (Karl Haushofer), przewidujące podział świata - w szczególności Południa - na kilka stref wpływów kontrolowanych przez najsilniejsze państwa, w ramach którego Rosja uzyskałaby dostęp do Oceanu Indyjskiego. ${ }^{45}$ Geopolityka w wydaniu przewodniczącego Liberalno-Demokratycznej Partii Rosji implikuje treści rasistowskie i nie stanowi zbyt poważnego wyzwania intelektualnego.

Odpowiedzią administracji kremlowskiej na wlewającą się w przestrzeń postradziecką falę „kolorowych rewolucji”, zwłaszcza po „rewolucji pomarańczowej” na Ukrainie, stała się koncepcja „demokracji suwerennej”, będąca przełożeniem na sferę polityki zagranicznej idei „demokracji kierowanej”. Została ona sformułowana przez Nikitę Garadżę, Aleksieja Czadajewa, Witalija Trietiakowa, Maksima Sokołowa, Andrieja Kokoszyna, i koordynującego cały projekt - Władisława Surkowa. ${ }^{46}$ „Demokracja suwerenna” miała zatem również swój wymiar geopolityczny, sprowadzający się do zasady pełnej niezależności (suwerenności) Rosji od zewnętrznych ośrodków siły. W tej perspektywie Rosja nie jest dyspozycyjna wobec Waszyngtonu czy Brukseli, natomiast staną się takimi reżimy ustanawiane w wyniku „kolorowych przewrotów”. Za jednego z ideowych patronów koncepcji „demokracji suwerennej” został uznany niemiecki politolog - w przeszłości główny jurysta Trzeciej Rzeszy, a po drugiej wojnie światowej geopolityk - Carl Schmitt (jeden z ulubionych myślicieli Aleksandra Dugina).

z 2000 r., suplementowanego inną książkową publikacją tego autora - Myslit' prostranstwom (Myśleć przestrzenia); А. Дугин, Основы геополитики.

43 Innymi znanymi pozycjami tego autora są: А. Дугин, Проект «Евразия», Москва 2004; А. Дугин, Тамплеры пролетариата. (Национал-Больщевизм и инициация), Москва 1997, А. Дугин, Философия войны, Москва 2004.

${ }^{44}$ Problem ten rozwinął w okresie międzywojennym zaliczany do twórców rosyjskiej geopolityki Piotr Sawickij; П. Савицкий, Месторазвитие русской промылиленности, Берлин 1932.

${ }^{45}$ В. Жириновский, О судьбах России (ч. 1: Уроки истории; ч. 2: Последний бросок на юг; ч. 3: С моей точки зрения), Москва 1993.

${ }^{46}$ Zob. I. Krastev, Suwerenna demokracja. Nowa rosyjska ideologia, „Dziennik”. Tygodnik idei „Europa” (dodatek), 26 sierpnia 2007, nr 34 (125); Суверенитет, ред. Н. Гараджа, Москва 2006; А. Чадаев, Путин. Его идеология, Москва 2006; К. Шмитт, Диктатура. От истоков современной идеи суверенитета до пролетарской классовой борьбы, ред. Д. Кузницын, пер. с нем. Ю. Коринц, Санкт-Петербург 2005. 
Schmitt słynął ze zdecydowanej krytyki systemu neoliberalnego (demokracji liberalnej) uosabianego przez Stany Zjednoczone oraz z wyznawania wspomnianego wyżej paradygmatu binarnego $\mathrm{w}$ geopolityce (rywalizacji mocarstw morskich i kontynentalnych jako głównego imperatywu historii ludzkości).

„Rewolucja pomarańczowa” na Ukrainie była sporym szokiem dla Moskwy, pozbawiła Kreml resztek złudzeń co do partnerskich wobec Rosji intencji Zachodu w przestrzeni postradzieckiej. Władze rosyjskie przekonały się, że nie tylko w skali globalnej, ale również regionalnej - w skali regionu uznawanego przez nie za tradycyjną strefę wpływów Rosji nie mogą liczyć na zachodnie zrozumienie i uwzględnianie rosyjskich interesów geopolitycznych. Dlatego też administracja prezydenta Władimira Putina zaczęła prowadzić asertywny dyskurs z Zachodem, a szczególnie ze Stanami Zjednoczonymi, co zamanifestowało się w zacieśnianiu relacji z Chinami w kwestii współpracy w Azji Środkowej (powołanie Szanghajskiej Organizacji Współpracy w 2005 r.) oraz w woli Moskwy zastąpienia nią dotychczasowej kooperacji rosyjsko-amerykańskiej. Symbolicznym wyrazem asertywnego kursu Kremla wobec Zachodu było wystąpienie Władimira Putina na 43. Konferencji Bezpieczeństwa w Monachium 10 lutego 2007 r., gdzie rosyjski przywódca zarzucił zachodnim, a zwłaszcza amerykańskim politykom ignorowanie interesów Rosji (na obszarze postradzieckim) oraz arbitralną politykę globalną (amerykańskie działania na Bliskim i Środkowym Wschodzie). Wystąpienie to można interpretować jako wyznaczenie przez Kreml Zachodowi „czerwonej linii” w przestrzeni postradzieckiej, której przekroczenie spotka się ze stanowczą i szybką reakcją Moskwy. Potwierdzeniem tego miały być wojna z Gruzją w sierpniu 2008 r. czy też polityka wobec Ukrainy po „eurorewolucji”" z przełomu 2013 i $2014 \mathrm{r}$.

Powstaje wobec tego pytanie - do czego dąży Rosja i jej obecne władze w odniesieniu do obszaru postradzieckiego, czy jest to dążenie do odbudowy imperium? Wiele - wydaje się - pomieszania w tej kwestii wprowadziła enuncjacja Władimira Putina z kwietnia 2005 r., że „rozpad ZSRR był największą katastrofą geopolityczną XX w.". ${ }^{47}$ Szczególnie w Polsce wyciąga się z tego oświadczenia wnioski o zamiarach restytucji przez Kreml dawnej przestrzeni imperialnej. Jednak zapomina się o innej wypowiedzi Władimira Putina z tego samego roku, że „kto nie tęskni za ZSRR nie ma serca, kto pragnie jego powrotu nie ma mózgu” ${ }^{48}$ Moskwa dąży zatem do konsolidacji swojej strefy wpływów na obszarze postradzieckim, uczynienia z państw graniczących bezpośrednio z Rosją (z wyjątkiem państw nadbałtyckich należących do NATO i Unii Europejskiej) pasa „przyjaznego sąsiedztwa" i ewentualnie satelizacji tego pasa. W tę koncepcję wpisuje się

${ }^{47}$ Słowa Władimira Putina pochodzą z „Orędzia do Zgromadzenia Federalnego Federacji Rosyjskiej” wygłoszonego 25 kwietnia 2005 r.; Послание Федеральному Собранию Российской Федерации, http://archive.kremlin.ru/appears/2005/04/25/1223_type63372type63374type82634 _87049.shtml [dostęp: 25 stycznia 2016].

${ }^{48}$ Путин считает, что распад СССР стал трагедией для миллионов, ia.ru/politics/20050505/39937603.html [dostęp: 25 stycznia 2015]. 
eliminacja zachodnich wpływów, zwłaszcza politycznych z przestrzeni postradzieckiej, integracja krajów Wspólnoty Niepodległych Państw w ramach struktur o charakterze polityczno-ekonomiczno-obronnym koordynowanych przez Moskwę, zapobieganie integracji euroatlantyckiej. O zaniepokojeniu ekspansją Paktu Północnoatlantyckiego na Wschód mają świadczyć słowa Władimira Putina zacytowane przez amerykańskiego ambasadora przy NATO, Kurta Volkera, wypowiedziane w kontekście szczytu NATO w Bukareszcie w kwietniu 2008 r., i opublikowane przez Wikileaks (wysłane przez Volkera w depeszy z tego szczytu), że „Ukraina jest sztucznym państwem powstałym z terytoriów Polski, Czechosłowacji, Rumunii i Rosji, a Krym został przekazany Ukrainie decyzją Biura Politycznego KPZR... 17 mln obywateli Ukrainy to Rosjanie, Ukraina otrzymała olbrzymią połać rosyjskiego terytorium. Jeśli teraz dodamy do tych problemów kwestię członkostwa w NATO, egzystencja tego państwa może być zagrożona". ${ }^{49}$ Trudno jest zweryfikować dosłowność powyższej wypowiedzi, przypisywanej przez amerykańskiego dyplomatę Władimirowi Putinowi, ale można założyć, że przynajmniej w połowie słowa te odzwierciedlają rzeczywiste poglądy Kremla na zagadnienie relacji Ukraina-NATO. Oczywiście, intencje i działania administracji kremlowskiej mają swój wymiar geopolityczny oraz geostrategiczny, służąc umocnieniu mocarstwowej podmiotowości Rosji i geopolitycznej racjonalizacji rosyjskich interesów na obszarze postradzieckim.

\section{KONKLUZJE}

Percepcja stosunków międzynarodowych wśród rosyjskiej klasy politycznej często odbywa się przez pryzmat geopolityki. Geopolityka stała się w toku postradzieckiej historii Rosji nie tyle ideologią zastępującą komunizm (jakkolwiek początkowo była nią niemal oficjalnie), ile światopoglądem. Geopolityka kształtuje obraz świata rosyjskich elit rządzących, jak również ich stosunek do świata, jest systemem wyjaśniającym Rosjanom świat i naturę stosunków międzynarodowych, pozycjonuje miejsce i rolę Rosji w świecie, stawiając przed nią określone zadania, wyzwania i misje dziejowe. I chociaż rosyjskie władze w swoim pragmatyzmie nie sięgają tak często po retorykę geopolityczną jak np. niektóre kręgi eksperckie czy środowiska inteligenckie, to świetnie zdają sobie sprawę z wartości (nośności) propagandowej geopolityki, posługując się nią jako instrumentem patriotycznej mobilizacji. Geopolityka stanowi również bardzo istotne kryterium definiowania przez Rosję swoich interesów narodowych oraz swojej racji stanu.

Współczesna Rosja, mimo iż jest sukcesorem Związku Radzieckiego, nie odziedziczyła po nim pełnego realnego statusu supermocarstwa, będąc zaledwie supermocarstwem wojskowym, lecz zachowując jako jedyne państwo na

${ }^{49}$ Zob. Silna Polska pomagała Gruzji, http://wyborcza.pl/1,76842,8746346,Silna_Polska_ pomagala_Gruzji.html?disableRedirects=true [dostęp: 25 stycznia 2016]. 
świecie parytet nuklearnego zniszczenia wobec Stanów Zjednoczonych. Potencjał gospodarczy, znacznie skromniejszy od potencjału gospodarczego Stanów Zjednoczonych, nie pozwala Rosji na prowadzenie aktywnej polityki globalnej, jakkolwiek nie uniemożliwia jej lokalnego wspierania swoich sojuszników daleko od swoich granic (konflikt w Syrii). Federacja Rosyjska jest mocarstwem regionalnym, dominującym w północnej i środkowej Eurazji, domagającym się od świata, zwłaszcza od Zachodu, uznania swojej supremacji i strefy wpływów w przestrzeni postradzieckiej. Utrwalaniu dominacji rosyjskiej na obszarze postradzieckim służą strategie pomocnicze, zaliczane do arsenału soft power, jak wspieranie i upowszechnianie rosyjskiej kultury i języka, zwłaszcza na terenach uznawanych za terytorium kanoniczne rosyjskiego prawosławia (Ukraina, Białoruś, północny Kazachstan).

Moskwa zamierza stanowczo i zdecydowanie przeciwdziałać ekspansji politycznej, ale też i ekonomicznej (na wielką skalę) na obszar postradziecki oraz wciąganiu krajów WNP w proces integracji euroatlantyckiej. Za szczególne zagrożenie dla Rosji Kreml uznaje działania, podejmowane głównie przez Stany Zjednoczone, na rzecz rozszerzenia NATO na wschód, a szczególnie objęcie nimi Ukrainy. Wspierany przez Zachód cykl postmodernistycznych rewolucji w przestrzeni postradzieckiej jest uznawany przez administrację kremlowską za wstęp do finalnej rewolucji w Moskwie. W realizacji swoich strategii na obszarze postradzieckim, dekonstruujących strefę wpływów Rosji, Zachód posługuje się bardziej wyrafinowanym niż rosyjski zestawem środków soft power, do których można zaliczyć atrakcyjność ekonomiczną, technologiczną czy instytucjonalną, co Moskwa stara się równoważyć zastosowaniem instrumentów hard power („,bicz” energetyczny, użycie sił zbrojnych). W tym kontekście na uwagę zasługuje stwierdzenie twórcy oraz dyrektora amerykańskiego ośrodka analitycznego Stratfor, Georga Friedmana, że rosyjskie działania zmierzające do odbudowy strefy wpływów w granicach dawnego ZSRR wydają się agresywne, jednak w rzeczywistości mają one charakter defensywny. ${ }^{50}$ Stwierdzenie to wyraźnie więc określa wyjściowe pozycje Rosji i Zachodu w rywalizacji o obszar postradziecki.

Odwoływanie się czy też apelowanie w trakcie ,geopolitycznej kontrofensywy" przez władze Rosji do określonych archetypów rosyjskiej tożsamości: ziemia rosyjska (terytoriocentryzm), język rosyjski (uniwersalizm kulturowy), prawosławie (ekskluzywizm cywilizacyjny) czy miejsc bohaterskich w historii Rosji (topofilia heroiczna oraz mitologia narodowa) ukierunkowuje świadomość zbiorową Rosjan na wyobrażenia kartograficzne, przypomina symbolikę i estetykę imperialną, wtłaczając rosyjskie myślenie o świecie i systemie międzynarodowym w geopolityczne koleiny. Służy to legitymizacji społecznego poparcia zarówno dla samych władz, jak i dla lansowanej przez nie wizji świata policentrycznego, ponieważ w świecie multilateralnym Rosja uzyskuje znacznie większe pole

${ }^{50}$ G. Friedman, Następne sto lat. Prognoza na XXI w., thum. M. Antosiewicz, Warszawa 2009, s. 126. 
manewru wobec globalnego hegemona - Stanów Zjednoczonych, skuteczniej zabezpieczając swoje interesy w geograficznym pasie postradzieckiej Eurazji. Obecny rewizjonizm Rosji i Zachodu na obszarze postradzieckim stanowi jeden z czynników najbardziej dynamizujących współczesne stosunki międzynarodowe i niosących ze sobą określone zagrożenia dla pokoju na świecie. Rewizjonizm ten jest silnie zdeterminowany przez geopolitykę i wynikającą z niej różnicę interesów zainteresowanych na tym obszarze graczy. Geopolityczna rywalizacja o strefy wpływów we współczesnym świecie staje się substytutem dawnej konfrontacji ideologicznej i tworzy w nim nowe linie podziałów.

\section{LITERATURA}

1. Anderson B., Wspólnoty wyobrażone: Rozważania o źródłach i rozprzestrzenianiu się nacjonalizmu, Społeczny Instytut Wydawniczy Znak, Kraków 1997.

2. Bieleń S. Geopolityczne uwarunkowania nowej tożsamości Rosji, [w:] Nowa tożsamość Niemiec i Rosji w stosunkach międzynarodowych, red. S. Bieleń, W. M. Góralski, Warszawa 1999.

3. Bieleń S., Tożsamość międzynarodowa Federacji Rosyjskiej, Oficyna Wydawnicza ASPRA-JR, Warszawa 2006.

4. Brzeziński Z., Wielka szachownica. Główne cele polityki amerykańskiej, przeł. T. Wyżyński, Wydawnictwo Bertelsmann Media, Wydawnictwo Świat Książki, Warszawa 1998.

5. Bratkiewicz J., Zapętlenia modernizacji. Szkice o samopostrzeganiu i autoidentyfikacji w interakcjach tradycji i nowoczesności (przypadek Rosji i nie tylko), Instytut Studiów Politycznych Polskiej Akademii Nauk, Warszawa 2007.

6. Bryc A., Cele polityki zagranicznej Federacji Rosyjskiej, Wydawnictwo Adam Marszałek, Toruń 2004.

7. Cohen S., Geography and Politics in World Divided, Random House, New York 1963.

8. Czajkowski M., Rosja w Europie. Polityka bezpieczeństwa europejskiego Federacji Rosyjskiej, Wydawnictwo Dante, Kraków 2003.

9. Friedman G., Następne sto lat. Prognoza na XXI w., thum. M. Antosiewicz, Wydawnictwo AMF Plus Group, Warszawa 2009.

10. Fukuyama F., Koniec historii, przekł. T. Bieroń, M. Wichrowski, Wydawnictwo Zysk i S-ka, Poznań 1996.

11. Huntington S. P., Zderzenie cywilizacji i nowy kształt ładu światowego, przeł. H. Jankowska, Warszawskie Wydawnictwo Literackie Muza, Warszawa 2001.

12. Gellner E., Narody i nacjonalizm, przekł. T. Hołówka, Państwowy Instytut Wydawniczy, Warszawa 1991.

13. Hobsbawm E., Narody i nacjonalizm po 1780, thum. J. Maciejczyk, M. Starnawski, Wydawnictwo Difin, Warszawa 2010.

14. Jean C., Geopolityka, przeł. T. Orłowski i J. Pawłowska, Wydawnictwo Zakład Narodowy im. Ossolińskich, Wrocław - Warszawa - Kraków 2003.

15. Kagan R., Powrót do historii i koniec marzeń, przeł. G. Sałuda, Dom Wydawniczy Rebis, Poznań 2009.

16. Kedourie E., Nationalism, Blackwell, London 1993. 
17. Krastev I., Putinowskie „spoleczeństwa obywatelskie”?, http://www.dziennik.pl/dziennik/europa/article47052/Putinowskie_spoleczenstwa_obywatelskie_html [dostęp: 26 października 2005].

18. Krastev I., Suwerenna demokracja. Nowa rosyjska ideologia, „Dziennik”. Tygodnik idei „Europa" (dodatek), 26 sierpnia 2007, nr 34 (125).

19. Marciniak W., Mapa i pamięć o imperium. Kartograficzne symbole nostalgii postsowieckiej, [w:] Inne wymiary polityki, red. idem, Instytut Studiów Politycznych Polskiej Akademii Nauk, Warszawa 2013.

20. Marciniak W., Przestrzeń czy pustka? Pojęcie „prostranstwo” w rosyjskich debatach politycznych lat dziewięćdziesiatych XX wieku, [w:] Ofiary imperium. Imperia jako ofiary. 44 spojrzenia, red. A. Nowak, Instytut Pamięci Narodowej, Instytut Historii Polskiej Akademii Nauk, Warszawa 2010.

21. Moczulski L., Geopolityka. Potęga w czasie i przestrzeni, Dom Wydawniczy Bellona, Warszawa 2000.

22. Orlov A., Russia Will Never Accept the Role of a Poor Relation, „International Affairs: A Russian Journal of World Politics, Diplomacy and International Relations” 2004, t. $50, \mathrm{nr} 4$.

23. Ó Tuathail G., Agnew J., Geopolitics and Discourse: Practical Reasoning American Foreign Policy, „Political Geography” 1992, nr 11.

24. Potulski J., Wprowadzenie do geopolityki, Wydawnictwo Uniwersytetu Gdańskiego, Gdańsk 2010.

25. Putin Has Just Put An End to the Wolfowitz Doctrine, http://www.washingtonsblog.com/2015/10/ putin-has-just-put-an-end-to-the-wolfowitz-doctrine.html [dostęp: 25 stycznia 2016].

26. Silna Polska pomagała Gruzji, http://wyborcza.pl/1,76842,8746346,Silna_Polska_pomagala_Gruzji.html?disableRedirects=true [dostęp: 25 stycznia 2016].

27. Sykulski L., Geopolityka, czyli pochwała realizmu. Szkice teoriopoznawcze, Warszawska Firma Wydawnicza s.c., Warszawa 2011.

28. Szymborski W., Doktryna Busha, Wydawnictwo Wers, Bydgoszcz 2005.

29. Świder K., Klub Izborski wobec Ukrainy, „Studia Polityczne” 2015, t. 38, nr 2.

30. U.S. Strategy Plan Calls for Insuring No Rivals Develop A One-Superpower World. Pentagon's Document Outlines Ways to Thwart Challenges to Primacy of America, by P. E. Tyler, „The New York Times", 8 marca 1992.

31. Walicki A., Do wojny potrzeba dwóch stron. Dlaczego Putin kazat zająć Krym i jaka w tym role odegraty Stany Zjednoczone, „Przegląd” 2015, nr 18 (800).

32. Wierzbicki A., Russkij mir jako projekt restauracyjny imperium, [w:] Rosja. Rozważania imperiologiczne, red. S. Bieleń, A. Skrzypek, Oficyna Wydawnicza ASPRA-JR, Warszawa 2015.

33. Буркин А., Возжеников А., Синеок Н., Национальная безопасность России в контексте современных политических процесов, РАГС, Москва 2005.

34. Дугин А., Основы геополитики. Геополитическое будущее России, Арктогея, Москва 2000.

35. Дугин А., Проект «Евразия», Яуза, Москва 2004.

36. Дугин А., Тамплеры пролетариата. (Национал-Большевизм и инициация), Арктогея, Москва 1997.

37. Дугин А., Философия войны, Яуза, Москва 2004.

38. Жириновский В., О судьбах России (ч. 1: Уроки истории; ч. 2: Последний бросок на юг; ч. 3: С моей точки зрения), Москва 1993.

39. Замятин Д., Власть пространства и пространство власти: Географические образы в политике и международных отношениях, РОССПЭН, Москва 2004. 
40. Замятин Д., Метагеография: Пространство образов и образы пространства, Аграф, Москва 2004.

41. Золотарев В., Военная безопасность Государства Российского, Кучково поле, Москва 2001.

42. Зюганов Г., География победы: Основы российской геополитики, Партийная печать КПРФ, Москва 1997.

43. Ионин Л., Социология культуры: Путь в новое тысячилетие. (Учебное пособие для студентов вузов), Москва 2000, rozdz. 5: Геополитика и глобализм, http://www.gumer. info/bibliotek_Buks/Sociolog/Ionin/_05_1.php [dostęp: 23 listopada 2015].

44. Колосов В., Российская геополитика: Традиционные концепиии и современные вызовы, „Общественные науки и современность” 1996, nr 3.

45. Константинов С., Ушаков А., История после истории. Образы России на постсоветском пространстве, АИРО-ХХ, Москва 2001.

46. Концепция национальной безопасности Российской Федерации, „Дипломатический вестник" 1998, nr 1.

47. Концеепии национальной безопасности Российской Федераџии, „Дипломатический вестник" 2000, $\mathrm{nr} 2$.

48. Послание Федеральному Собранию Российской Федерации, http://archive.kremlin.ru/appears/2005/04/25/1223_type63372type63374type82634_87049.shtml [dostęp: 25 stycznia 2016].

49. Путин считает, что распад СССР стал трагедией для миллионов, ia.ru/politics/20050505/39937603.html [dostęp: 25 stycznia 2015].

50. Савицкий П., Месторазвитие русской промышленности, Издание Евразийцев, Берлин 1932.

51. Стратегия национальной безопасности Российской Федераџии до 2020 года, http://base. garant.ru/195521/\#block_1000 [dostęp: 25 lipca 2015].

52. Суверенитет, ред. Н. Гараджа, Европа, Москва 2006.

53. Чадаев А., Путин. Его идеология, Европа, Москва 2006.

54. Шмитт К., Диктатура. От истоков современной идеи суверенитета до пролетарской классовой борьбы, ред. Д. Кузницын, пер. с нем. Ю. Коринц, Наука, Санкт-Петербург 2005.

55. Якунин В., Формирование геостратегий России, Мысль, Москва 2005.

\section{GEOPOLITICS AS THE WORLD VIEW OF AUTHORITY IN RUSSIA}

Abstract: The purpose of this article is to present the characteristics and motives of thinking about international relations showed by the Russian ruling elite. This thinking is determinated by geopolitics. Russian political class is not the only one in the world establishment, which is based on its perception of the world system on geopolitical interpretations, because a similar trend can be observed in the American and Chinese approaches to these issues. Recognition of Southeast Asia and the adjacent area of the Pacific in recent years by Washington as the most important global policy direction of the United States is a confirmation of such tendency. Nevertheless, geopolitics in Russia becomes a field of knowledge, which is incoporated into the new Russian messianism, being one of the cornerstones of the Russian historical destination and filling Russian historiosophy with new content. Special status of geopolitics in Russia due to the fact that already in the 90s of the 20th century it became an ideology, which filled the ideological vacuum after the bankrupt communist ideology. Thus, in this country there has been a process of ideologisation of geopolitics, which gives it the position of the new universal idea - integrally explaining Russians, and primarily the Russian ruling elite, the surrounding world. Geopolitics and imposed by it determined 
geographically and by thinking in the traditional categories of zones of influence vision of the international system has become both worldview authority in Russia and an essential element of the Russian strategic culture. In the article will be presenting conditions that make the geopolitics the permanent, archetypical component of thinking about the world and global order from viewpoint of the ruling elite in Russia.

Key words: Russia, geopolitics, power elite, strategic culture, global order 